\title{
PELATIHAN DAN PENDAMPINGAN PENERAPAN TEKNIKMEMBACA SKIMMING DALAM MENJAWAB SOAL UJIAN NASIONAL BAHASA INDONESIA
}

\author{
Muhammad Zikri Wiguna $^{1}$, Muhammad Thamimi ${ }^{2}$, Fitri Wulansari ${ }^{3}$ \\ ${ }^{1,2,3}$ Program Studi Pendidikan Bahasa dan Sastra Indonesia Fakultas Bahasa dan Seni \\ IKIP PGRI Pontianak, Jalan Ampera No. 88 \\ e_mail: zeskarind.zack@gmail.com
}

\begin{abstract}
Abstrak
Tujuan pengabdian adalah untuk memberikan pelatihan kepada para siswa dan guru bahasa Indonesia di SMP Pancasila Kecamatan Sungai Kakap Kabupaten Kubu Raya tentang pelatihan dan pendampingan penerapan teknik membaca skimming dalam menjawab soal ujian nasional bahasa Indonesia. Kegiatan pelatihan diikuti oleh siswa-siswi dan guru bahasa Indonesia yang berada di SMP Pancasila berjumlah 45 orang. Pelaksanaan kegiatan dilakukan di ruang aula SMP Pancasila. Pelaksanaan kegiatan pelatihan dilakukan dengan menggunakan metode praktik, yaitu memberikan materi terlebih dahulu kepada peserta pelatihan (guru bahasa Indonesia dan siswa) dan kemudian dilakukan proses pembimbingan dalam melakukan praktik menerapkan teknik membaca skimming. Berdasarkan hasil evaluasi kegiatan yang telah dilakukanpeserta memiliki antusias yang tinggi dan memiliki sikap positif dalam memahami soal UN Mata Pelajaran Bahasa Indonesia. Hal ini tampak setelah mengikuti pendamping dan pelatihan peserta memahami secara garis besar tentang penerapan teknik membaca skimming dalam menjawab soal UN. Berdasarkan angket diketahui pula kegiatan pengabdian yang dilakukan memiliki manfaat yang dapat diterapkan dalam proses pembelajaran.
\end{abstract}

Kata Kunci : Membaca, Teknik Skimming, UN Bahasa Indonesia

\begin{abstract}
The purpose of service is to provide training to Indonesian language students and teachers at Pancasila Middle School Sungai Kakap Sub-District, Kubu Raya District about training and mentoring in the application of skimming reading techniques in answering Indonesian national exam questions. The training activities were attended by 45 Indonesian students and teachers in Pancasila Middle School. The activity was carried out in the Pancasila Middle School hall. The implementation of the training activities is carried out using the practice method, which is to provide the material first to the trainees (Indonesian language teachers and students) and then a coaching process is carried out in practicing the skimming reading technique. Based on the results of the evaluation of activities that have been carried out participants have high enthusiasm and have a positive attitude in understanding the subject matter of Indonesian Language Subjects. This was evident after participating in the companion and training the participants understood in broad outline the application of skimming reading techniques in answering UN questions. Based on the questionnaire it is known that the service activities carried out have benefits that can be applied in the learning process.
\end{abstract}

Keywords: Reading, Skimming Technique, Indonesian Language Examination 


\section{PENDAHULUAN}

Ujian Nasional biasa disingkat UN adalah sistem evaluasi standar pendidikan dasar dan menengah secara nasional dan persamaan mutu tingkat pendidikan antar daerah yang dilakukan oleh pusat penilaian pendidikan, Depdiknas di indonesia berdasarkan Undang-Undang Republik Indonesia Nomor 20 Tahun 2003 menyatakan bahwa dalam rangka pengendalian mutu pendidikan secara nasional dilakukan evaluasi sebagai bentuk akuntabilitas penyelenggara pendidikan kepada pihak-pihak yang berkepentingan. Lebih lanjut dinyatakan bahwa evaluasi dilakukan oleh lembaga yang mandiri secara berkala, menyeluruh, transparan dan sistematik untuk menilai pencapaian standar nasional pendidikan dan proses pemantauan evaluasi tersebut harus dilakukan secara berkesinambungan.

Proses pemantauan evaluasi tersebut dilakukan secara terus menerus dan berkesinambungan pada akhirnya akan dapat membenahi mutu pendidikan. Pembenahan mutu pendidikan dimulai dengan penentuan standar. Penentuan standar yang terus meningkat diharapkan akan mendorong peningkatan mutu pendidikan, yang dimaksud dengan penentuan standar pendidikan adalah penentuan nilai batas (cut off score). Seseorang dikatakan sudah lulus/kompeten bila telah melewati nilai batas tersebut berupa nilai batas antara peserta didik yang sudah menguasai kompetensi tertentu dengan peserta didik yang belum menguasai kompetensi tertentu. Bila itu terjadi pada ujian nasional atau sekolah maka nilai batas berfungsi untuk memisahkan antara peserta didik yang lulus dan tidak lulus disebut batas kelulusan, kegiatan penentuan batas kelulusan disebut standard setting.

Mata pelajaran bahasa Indonesia merupakan satu diantara mata pelajaran yang diujikan. Tentunya kami memandang perlunya persiapan-persiapan bagi siswa-siswi dalam rangka menghadapi soal Ujian Nasional khususnya bahasa Indonesia.Pembelajaran bahasa Indonesia diarahkan untuk pencapaian standar kompetensi yang telah dirumuskan dan dijabarkan menjadi kompetensi dasar. Pembelajaran tersebut mencakup empat aspek keterampilan berbahasa yaitu, mendengarkan, berbicara, membaca, dan menulis. Pembelajaran bahasa Indonesia 
selama ini kurang melatih siswa dengan menggunakan bahasa sebagai alat komunikasi baik secara lisan maupun tulisan. Siswa harus lebih banyak diberikan latihan-latihan yang mengarah pada kemampuan membaca dan menulis.

Satu di antara foktor yang sangat mendukung proses pembelajaran adalah ketepatan dalam memilih dan menerapkan pendekatan, teknik, dan metode dalam pembelajaran. Pendekatan, teknik, dan metode harus sangat memperhatikan kadar keaktifan siswa agar pembelajaran menjadi bermakna. Dalam hal ini, siswa lebih memposisikan dirinya sebagai individu yang memerlukan suatu bekal untuk hidup nanti kedepannya. Mereka mempelajari apa yang bermanfaat bagi dirinya dan berupaya menggapainya.

Adanya pengabdian seperti pelatihan dan pendampingan ini untuk persiapan siswa-siswi menjawab soal-soal Ujian Nasional Bahasa Indonesia dengan menggunakan teknik membaca skimming. Dengan pelatihan dan pendampingan ini, agar siswa-siswi SMP bisa dan siap untuk menjawab soal-soal Ujian Nasional. Selain siap dan bisa menjawab soal-soal Ujian Nasional, siswa juga mempunyai keterampilan mengenai membaca skimming. Membaca cepat mencakup dua jenis kegiatan yakni skimming dan scanning. Skimming merupakan teknik membaca cepat untuk mencari hal-hal yang penting dari suatu bacaan. Sedangkan scanning merupakan suatu teknik membaca untuk mendapatkan suatu informasi tanpa bacaan yang lain-lainnya. Hambatanhambatan dalam membaca cepat ini antara lain:

1) Vokalisasi, yaitu membaca dengan bersuara

2) Gerakan bibir, yaitu mengucapkan kata demi kata apa yang dibaca dengan

3) menggerakkan bibirGerakan kepala, yaitu membaca dengan menggerakkan kepala dari kiri ke kanan dan sebaliknya

4) Menunjuk dengan jari, yaitu membaca sambil menunjuk kata yang kitabaca dengan jari

5) Regresi, yaitu mengulang-ulang kata yang telah dibaca

6) Subvokalisasi, yaitu melafalkan dengan batin/pikiran kata-kata yang dibaca 
Membaca cepat dapat diartikan juga sejenis membaca yang membuat mata kita bergerak lebih cepat melihat dan memerhatikan bahan tulisan untuk mencari serta mendapatkan informasi. Kalau kita tidak tahu bagaimana cara membaca cepat dan kapan harus melakukannya, kita akan menghadapi kesulitan dalam menyelesaikan bacaan yang diinginkan. Membaca cepat adalah keterampilan memilih isi bahan yang harus dibaca sesuai dengan tujuan kita, yang ada relevansinya dengan kita, tanpa membuangbuang waktu untuk menekuni bagianbagian lain yang tidak kita perlukan. Dengan demikian menurut Atikah membaca cepat merupakan salah satu kegiatan membaca yang menitikberatkan pada pemahaman isi bacaan secara tepat dengan waktu yang relatif singkat. Jadi, ada dua faktor yang memang penting dalam membaca cepat yaitu kecepatan dan ketepatanMembaca cepat merupakan suatu keterampilan yakni bahwa keterampilan itu dapat dilatih. Keberhasilan anda dalam menguasai dan mempraktikkan teknik membaca cepat akan sangat bergantung pada sikap, keseriusan, dan kesiapan untuk mencoba melatihkan teknik tersebut. Untuk itu, apabila Anda merasa belum dapat membaca cepat, Anda harus berkeinginan untuk memperbaiki dan merasa yakin bahwa akan dapat melakukan hal itu. Metode membaca cepat tergantung pada beberapa tujuan atau pertanyaan yang telah ditentukan sebelumnya. Hal ini dilakukan dengan tujuan untuk memahami intisari bacaan, bukan bagian-bagian perinciannya yang detail-detail.

Metode membaca cepat menuntut kecepatan yang paling tinggi. Strategi membaca cepat dilakukan dengan tujuan untuk memahami intisari bacaan, bukan rincian yang mendetail. Oleh karena itu, strategi ini menuntut kecepatan yang paling tinggi yang dapat dilakukan seseorang. Kecepatan yang tinggi menyebabkan lompatan-lompatan dalam membaca. Terdapat bagian-bagian tertentu dari bacaan yang dilompati. Tentu saja itu adalah bagian yang tidak esensial. Bagian yang tidak esensial ini antara lain bagian yang tidak perlu mendapat respons, atau kalimat-kalimat yang tidak menimbulkan hilang jejak jika dihilangkan. Dengan kata lain, yang menjadi objek bacaan hanyalah kata-kata kunci yang serat dengan makna. Kalau kita bisa membaca dengan cepat, kita akan lebih banyak memiliki waktu ekstra untuk pekerjaan dluar belajar, bisa bersenang- 
senang bermain game pada komputer, olah raga, aktif diorganisasi, ataupun menonton film. Sementara yang membaca lambat, masih saja membolak-balik buku, tanpa habis-habisnya. Oleh karena itu kita harus berlatih membaca cepat. Skimming dimulai dengan previewing yaitu membaca cepat judul, subjudul, lalu membaca kalimat pertama atau terakhir dari setiap paragraf karena biasanya ide pokok ada pada posisi itu. Pembaca menggunakan skimming untuk mencari informasi khusus, bukan pemahaman secara menyeluruh. Ide pokok juga akan tergambar pada fakta yang diberikan pada tabel, grafik atau bagan. secara garis besar, maka langkah-langkah membaca teknik skimming adalah:

1) Membuat pertanyaan tentang apa yang akan kita cari dari suatu buku

2) Telusuri daftar isi atau mengantar, apakah informasi yang kita butuhkan itu ada

3) Dengan penuh perhatian, bukalah halaman demi halaman

4) Membaca judul dan sub-judul yang ada

5) Membaca dengan kecepatan tinggi pada bacaan yang sudah ditemukan

6) Berhentilah ketika merasa menemukan apa yang anda cari

7) Bacalah dengan kecepatan normal, dan pahami dengan baik yang anda cari tersebut.

Teknik membaca skimming adalah suatu teknik membaca dengan kecepatan tinggi untuk mencari hal-hal yang penting atau ide-ide pokok dari suatu bacaan. Menurut Soedarso (2010: 88) "Ciri khusus teknik skimming adalah menelusuri awal paragraf yang memuat ide pokok. Lalu dengan cepat bergerak ke bagian lain paragraf itu dan berhenti jika menemukan detail pentingnya, kemudian bergerak cepat lagi dan berhenti lagi untuk memungut detail atau gagasan yang penting”. Keterampilan membaca yang sangat berguna adalah membaca skimming yang melibatkan pembaca secara sepintas dan cepat untuk mendapatkan kesan keselurahan dan umum. Adapun manfaat dalam keterampilan membaca skimming yaitu, pertama dapat mencari suatu informasi khusus dalam suatu bacaan secara cepat dan efisien. Kedua, dapat menjelajahi banyak halaman dengan waktu yang singkat, dan ketiga tidak banyak membuang waktu untuk mencari sesuatu yang diinginkan dalam bacaan, khususnya tindakan yang tidak menunjang terhadap pencarian informasi tersebut.

Teknik membaca skimming dapat diartikan dengan mebaca garis besar (sekilas) untuk mendapatkan gambaran umum isi buku. Dalam penggunaan teknik ini ditekankan untuk mecari ide pokok yang berisi intisari sebuah bacaan. Teknik 
ini biasanya digunakan ketika akan mencari sesuatu yang khusus dari sebuah bacaan. Teknik skimming juga memiliki karekteristik yang husus yaitu dengan menelusuri awal paragraf yang memuat ide pokok. Lalu dengan cepat bergerak ke bagian lain paragraf itu dan berhenti jika menemukan detail pentingnya, kemudian bergerak cepat lagi dan berhenti lagi untuk memungut detail atau gagasan yang penting itu. Karakteristik yang menonjol dari teknik ini adalah dimulai dengan kegiatan previewing, yaitu membaca cepat judul, sub judul lalu mebaca kalimat pertama atau terakhir dari setiap paragraf karena biasanya ide pokok ada pada posisi itu.

Menurut Admin (2012: 26) membaca-sekilas (skimming) adalah membaca dengan cepat untuk mengetahui isi umum atau bagian suatu bacaan.Membacasekilas (skimming) adalah sejenis membaca yang membuat mata kita bergerak dengan cepat melihat, memperhatikan bahan tertulis untuk mencari serta mendapatkan informasi (Tarigan, 2008:33). Pengertian lain dari membaca skimming adalah membaca sekilas atau membaca cepat untuk mendapatkan suatu informasi dari yang kita baca. Skimming dilakukan untuk melakukan pembacaan cepat secara umum dalam suatu bahan bacaan. Dalam skimming, proses membaca dilakukan secara melompat-lompat dengan melihat pokok-pokok pikiran utama dalam bahan bacaan sambil memahami tema besarnya.

1) Tujuan Teknik Skimming

a. Untuk mengenali topik pacaan

b. Untuk mengetahui pendapat orang lain

c. Untuk mengetahui organisasi penulisan

d. Untuk mendapatkan bagian penting yang kita perlukan tanpa membaca keseluruhan

2) Manfaat Teknik Skimming

a. Dapat mencari informasi khusus yang diperlukan dari sebuah teks bacaan atau buku secara cepat dan efisien

b. Dapat menjelajahi banyak halaman buku dalam waktu yang singkat 
c. Tidak terlalu banyak membuang-buang waktu mencari sesuatu yang diinginkan dari buku, khususnya tidakan yang menunjang terhadap pencarian informasi tersebut.

Macam-macam teknik Skimming

Pembaca yang efisien mempunyai kecepatan membaca yang bermacam macam, sesuai dengan bahan yang dihadapi dan keperluannya umumnya dapat

dirinci sebagai berikut:

1) Membaca secara skimming dan scanning (kecepatan lebih $1.000 \mathrm{kpm}$ ) digunakan untuk :

a. Mengenal bahan yang akan dibaca

b. Mencari jawaban atas pertanyaan tertentu

c. Mendapatkan struktur dan organisasi bacaan serta menemukan gagasan umum dari bacaan itu

2) Membaca dengan kecepatan yang tinggi $(500-800 \mathrm{kpm})$ digunakan untuk:

a. Membaca bahan-bahan yang mudah dan dan telah dikenali

b. Membaca novel ringan untuk mengikuti jalan ceritanya

3) Membaca secara cepat $(350-500 \mathrm{kpm})$ digunakan untuk:

a. Membaca bacaan yang mudah dalam bentuk deskriptif dan bahan-bahan nonfiksi lain yang bersifat informatif

b. Membaca fiksi yang agak sulit untuk menikmati keindahan sastranya dan mengantisipasi akhir cerita

4) Membaca dengan kecepatan rata-rata (250-350 kpm) digunakan untuk:

a. Membca fiksi yang kompleks untuk analisis watak serta jalan ceritanya

b. Membaca nonfiksi yang agak sulit, untuk mendapatkan detail, mencari hubungan, atau membuat evaluasi ide penulis.

5) Membaca lambat (100-125 kpm) digunakan untuk:

a. Mempelajari bahan-bahan yang sulit dan menguasai isinya

b. Menguasai bahan-bahan yang sulit dan untuk menguasai isinya

c. Membuat analisis bahan-bahan bernilai sastra klasik

d. Memecahkan persoalan yang ditunjuk dengan bacaan yang bersifat intruksional (pedoman) 
Namun, menurut Sugono, kecepatan membaca berbeda bagi setiap orang, bergantung pada jenjang usianya. Menurut penelitian para ahli, kecepatan membaca bagi orang dewasa antara 900-1.000 kata per menit, bagi siswa sekolah.

Sudarso (2006: 16) mengatakan bahwa teknik skimming digunakan dalam membaca dengan tujuan seperti:

1. Mengenal topik bacaan,

2. Mengetahui opini orang terhadap topik yang dibahas,

3. Mendapatkan bagian penting yang kita perlukan tanpa membaca seluruh teks,

4. Mengetahui organisasi penulisan,

5. Penyegaran terhadap apa yang telah dibaca.

Menurut Noer (2009:23) skimming dilakukan untuk melakukan pembacaan cepat secara umum dalam suatu bahan bacaan. Dalam skimming, proses membaca dilakukan secara melompat-lompat dengan melihat pokok-pokok pikiran utama dalam bahan bacaan sambil memahami tema besarnya.Selain untuk melakukan pembacaan sekilas, skimming juga berguna dalam banyak proses membaca lainnya.

Menurut Noer (2009:26) ada beberapa alasan mengapa skimming dapat dilakukan tanpa harus terlalu khawatir kehilangan makna adalah:

1. Kebanyakan kalimat hanya memiliki beberapa kata penting yang menjadi pembentuk strukturnya. Dengan menghilangkan kata-kata lain yang tidak terlalu penting, maka makna kalimat sudah dapat ditangkap tanpa harus kehilangan makna sesungguhnya. Pada kesempatan yang akan datang saya akan membahas hal ini yang dikenal pula dengan nama telegraphic reading.

2. Dalam bahan bacaan yang cukup tebal, tidak semua bagian memiliki tingkat kesulitan yang sama. Ada bagian tertentu yang memang relatif lebih ringan dan mudah dipahami dibandingkan dengan bagian yang lain. Bagian yang ringan dapat dibaca dengan sangat cepat lewat skimming sedangkan bagian yang lebih sulit dibaca secara lebih lengkap dan teliti.

3. Ada kata-kata tertentu yang sangat penting dan berperan dalam membentuk struktur kalimat yakni subjek dan predikat. 
Widiatmoko (2011: 27) menyatakan beberapa manfaat membaca cepat yaitu:

1. Memperoleh kesan umum dari suatu buku, artikel atau tulisan singkat.

2. Menemukan hal tertentu dari suatu bacaan.

3. Mencari informasi yang diperlukan dari suatu bacaan.

4. Menelusuri bahan halaman buku atau bacaan dalam waktu singkat.

5. Tidak membuang-buang waktu

6. Membaca cepat menciptakan efisiensi

7. Semakin sedikit waktu yang diperlukan untuk melakukan hal-hal rutin, semakin banyak waktu yang tersedia untuk mengerjakan hal penting lainnya.

8. Membaca cepat memiliki nilai yang menyenangkan/menghibur.

9. Membaca cepat memperluas cakrawala mental.

10. Membaca cepat membantu berbicara secara efektif.

11. Membaca cepat membantu dalam menghadapi ujian.

12. Membaca cepat meningkatkan pemahaman.

13. Membaca cepat menjamin kita untuk selalu meng-up date informasi.

Adanya teknik skimming ini, siswa dituntut untuk memfokuskan pandangan hanya pada unsur-unsur yang penting saja. Jadi, tidah semua kata dalam soal yang harus dibaca siswa karena tidak semua kata dalam soal yang tercetak itu dibutuhkan siswa. Pada kegiatan ini siswa dilatih untuk melebarkan pandangan hanya pada bagian-bagian tertentu yang dianggap penting saja. Dengan selalu melompati atau melewati hal-hal yang dianggap tidak penting. Apabila siswa sudah mendapat kata atau kalimat yang dicarinya maka siswa dapat menandainya.

Berdasarkan dari uraian di atas, tampaknya perlu dilakukan suatu kegiatan yang mampu meningkatkan keterampilan membaca untuk siswa-siswi SMP untuk persiapan mengahadapi Ujian Nasional nanti. Kegiatan PPM ini akan dilakukan di SMP Pancasila Kecamatan Sungai Kakap Kabupaten Kubu Raya. Kegiatan PPM diusulkan ini menekankan pada kemampuan dan keterampilan membaca skimming untuk siswa-siswi SMP Pancasila agar tercapainya kelulusan yang optimal di Ujian Nasional nanti. 


\section{METODE}

Kegiatan pengabdian yang dilakukan yaitu pelatihan dan pendampingan penerapan teknik membaca skimming dalam menjawab soal ujian nasional bahasa indonesia Kegiatan pelatihan dilakukan dengan metode praktik, yaitu memberikan materi terlebih dahulu kepada peserta pelatihan (guru bahasa Indonesia dan siswa) dan kemudian dilakukan proses pembimbingan guru dalam melakukan praktik menerapkan teknik membaca skimming.

Peserta pelatihan adalah siswa-siswi kelas IX dan guru bahasa Indonesia yang berada di lingkungan SMP Pancasila Kecamatan Sungai Kakap yang berjumlah 45 orang. Kegiatan pelatihan dan pendampingan dilakukan berlangsung dalam tiga sesi, yaitu sesi penyampaian materi, sesi pelatihan dan sesi pendampinga/praktik. Saat sesi materi, tutor pelatihan memaparkan materi kepada para peserta dan kemudian dilanjutkan sesi kedua peserta mengikuti setiap tahap pelatihan dengan didampingi oleh tim dosen. Setelah pelatihan selesai dan para peserta sudah memahami setiap tahapan dalam teknik membaca skimming, maka dilanjutkan pada sesi pendampingan oleh tim tutor sampai perserta benar-benar paham.

Sesi praktik yaitu memberikan kesempatan kepada peserta pelatihan untuk menjawab contoh soal Ujian Nasonal bahasa Indonesia yang sudah diberikan Pada saat kegiatan berlangsung. Di akhir kegiatan, para peserta diminta untuk mengisi angket untuk melihat respon terhadap kegiatan pelatihan dan pendampingan yang telah dilaksanakan.

\section{HASIL DAN PEMBAHASAN}

Kegiatan pengabdian kepada masyarakat dilaksanakan melalui beberapa proses. Dalam proses sebelum pelaksanaan, tim pengabdian pada masyarakat yaitu dosen dari Program Studi Pendidikan Bahasa dan Sastra Indonesia melakukan koordinasi dengan sekolah mitra. Sekolah mitra yang dipilih untuk pelaksanaan kegiatan yaitu SMP Pancasila Kecamatan Sungai Kakap Kabupaten Kubu Raya.

Koordinasi yang dilakukan berkaitan dengan waktu pelaksanaan, tempat kegiatan, dan peserta yang akan dilibatkan dalam pelaksanaan kegiatan. Hasil dari 
koordinasi yang telah dilakukan, diputuskan bahwa pelaksanaan kegiatan pengabdian kepada masyarakat dilaksanakan pada tanggal 31 Oktober s.d. 2 November 2018. Tempat kegiatan dilaksanakan di ruang aula yang berada di SMP Pancasila. Peserta yang dilibatkan adalah seluruh siswa-siswi dan guru mata pelajaran bahasa Indonesia di SMP Panacasila Kecamatan Sungai Kakap Kabupaten Kubu Raya.

Proses selanjutnya adalah pelaksanaan kegiatan pengabdian kepada masyarakat. Pelaksanaan kegiatan dilakukan dalam 3 (tiga) tahap yaitu kegiatan pembuka, kegiatan inti, dan kegiatan penutup. Pada tahap pertama tanggal 31 Oktober 2018 yang dilaksanakan yaitu dengan penyelesaian administrasi/registrasi bagi peserta pelatihan yang dilaksakan selama 30 menit dimulai pada pukul 08.30 WIB dengan jumlah peserta yang telah melakukan registrasi sebanyak 45 peserta. Setelah registrasi dilakukan kegiatan pemberian materi selama 35 menit oleh ketua TIM pelaksana kegiatan pengabdian, tentang materi Membaca Skimming dan membahas Soal UN Mata Pelajaran Bahasa Indonesia oleh nara sumber kepada peserta.

Pembahasan materi menggunakan powerpint. Setelah selesai pemberian materi diadakan sesi tanya jawab/kuis Peserta yang bisa menjawab pertanyaan diberikan reward berupa buku Soal UN SMP 2019. Kegiatan simulasi menjawab soal UN Mata Pelajaran Bahasa Indonesia berlangsung dengan tertib. Kegiatan simulasi dilakukan selama 60 menit dengan memberikan sesi latihan kepada peserta, pemateri menampilkan dengan powerpoint dalam bentuk soal pilihan ganda dan peserta menerapkan penggunaan teknik membaca skimming untuk menjawab soal yang diajukan.

Kemudian dari tanggal 1 s.d. 2 November 2018 dilakukan bentuk pendampingan menjawab contoh soal Ujian Nasional menggunakan teknik membaca skimming oleh tim dosen kepada seluruh peserta kegiatan. Selama pelaksanaan kegiatan, peserta merespon dengan baik pada materi yang disampaikan. Peserta yang kurang mengerti tidak segan untuk langsungmengajukan pertanyaan. Kesulitan yang dihadapi oleh para peserta selanjutnya diselesaikan dengan bantuan dari dosen-dosen pembimbing kegiatan. Diakhir pelaksanaan kegiatan, tim dosen memberikan angket kepada seluruh 
peserta. Angket yang diberikan berkaitan dengan seluruh rangkaian kegiatan yang telah dilaksanakan.

Melihat respon positif dari seluruh peserta berdasarkan angket yang diberikan, maka kegiatan pengabdian kepada masyarakat yang telah dilaksanakan oleh dosen Prodi pendidikan bahasa dan sastra indonesia dapat disimpulkan berjalan dengan baik dan memberikan dampak yang positif. Dengan melihat hasil tersebut, maka perlu adanya pembahasan lebih lanjut berkaitan dengan kelanjutan dari kegiatan yang telah dilaksanakan.

Berdasarkan hasil wawancara yang telah dilakukan, sebagian besar peserta mengharapkan adanya kegiatan lanjutan. Keseluruhan kegiatan yang telah dilaksanakan dan melihat respon yang diberikan oleh para peserta kegiatan, maka perlu menjadi suatu pemikiran bagi dosen di lingkungan IKIP PGRI Pontianak khususnya Prodi Pendidikan Bahasa dan Sastra Indonesia untuk terus berkontribusi dalam merumuskan upaya-upaya dalam memberikan solusi perbaikan kualitas proses pembelajaran khususnya pada mata pelajaran Bahasa Indonesia.

\section{SIMPULAN}

Berdasarkan hasil analisis yang telah dilakukan terkait kegiatan pengabdian kepada masyarakat, diketahui bahwa setelah diberikan pendampingan dan pelatihan peserta memiliki antusias yang tinggi dan memiliki sikap positif dalam memahami soal UN Mata Pelajaran Bahasa Indonesia. Hal ini tampak setelah mengikuti pendamping dan pelatihan peserta memahami secara garis besar tentang penerapan teknik membaca skimming dalam menjawab soal UN. Berdasarkan angket diketahui pula kegiatan pengabdian yang dilakukan memiliki manfaat yang dapat diterapkan dalam proses pembelajaran selanjutnya, materi kegiatan sesuai dengan yang peserta butuhkan, pelaksanaan kegiatan sudah sesuai dengan keinginan para peserta. Peserta juga mengharapkan adanya keberlanjutan dari kegiatan yang telah dilaksanakan, dan para peserta menyatakan bahwa kegiatan yang dilaksanakan menambah wawasan. 


\section{UCAPAN TERIMA KASIH}

Terima kasih diucapkan kepada pihak mitra pengabdian kepada masyarakat yakni siswa-siswi SMP Pancasila serta dewan guru dan Kepala SMP Pancasila Kecamatan Sungai Kakap Kabupaten Kubu Raya atas partisipasinya dan kerjasamanya, serta pihak IKIP PGRI Pontianak yang telah mendukung memberikan bantuan dana untuk kelancaran kegiatan pengabdian kepada masyarakat.

\section{DAFTAR PUSTAKA}

Admin. 2012. Teknik Membaca Cepat Skimming dan Scanning. Jakarta: Atmajaya.

Noer, Muhammad. 2009. Speed Reading for Beginners. http://www.Muhammad Noer.com diunduh tanggal 17 November 2018.

Soedarso, 2010. Speed Reading Sistem Membaca Cepatdan Efektif. Gramedia Pustaka Utama. Jakarta.

Tarigan, Henry Guntur. 2008. Membaca Sebagai Suatu Keterampilan Berbahasa. Bandung: Angkasa.

Widiatmoko. 2011. Super Read Speed Reading. Jakarta: Gramedia. 